\title{
Searching for a Programme, Searching for an Identity, or the Association and the Struggle between The Saint Wenceslas and Hus-Hussite Traditions in Czech Music of the Second Half of the 19th Century
}

\section{Viktor Velek}

Although the chosen topic may at first glance appear to be two separate topics, and is usually dealt with as such, there is also the possibility of a synthesising approach, which is the case with this text. In a way, it follows on from a study examining the incorporation of the emerging Hussitism into the already existing Saint Wenceslas tradition. ${ }^{1}$ A similar-in a way parallel—process was also under way in the 19th century, when the natural formation of another developmental layer of the Saint Wenceslas tradition took place, and along with it the historicism-evoked interest in complex and critical knowledge of the tradition as a whole. At the same time, however, a new tradition, namely the phenomenon of "Master Jan Hus and Hussitism", was being discovered. The issue of the reform theologian burnt at the stake in Constance in 1415 and the subsequent destruction of the state during the Hussite wars had been taboo since the days of the anti-Reformation Emperor Ferdinand II of the House of Habsburg. That resulted in a certain split development: especially in the territory of today's Germany and France, a distinctive Hus-Hussite reception developed, but in the Czech territory the awareness of the tradition survived underground and in anti-Reformation rhetoric until the Napoleonic Wars. These opened the topic in the domestic environment, which was significantly reflected in the formation of a new paradigm of Czech (and, in fact, European) historiography and in the development of new interpretive approaches. It was not until the second half of

1 Viktor Velek, "Saint Wenceslaus in the Musical Context of the Bohemian Reformation", in The Bohemian Reformation and Religious Practice, Vol. 8 / Filosofický časopis, Special Issue No. 3, ed. Zdeněk V. David and David R. Holeton (Praha: Filozofický institut Akademie věd ČR, 2011), 190-197. 
the 19th century that the discovered phenomenon of "Master Jan Hus and Hussitism" was incorporated into the context of Czech national spiritual traditions. During the period in question, the Saint Wenceslas and Hus-Hussite traditions developed both separately and synthetically (association), but sometimes the traditions were put by contemporaries against each other (struggle). In any case, together with Slavic patriotism, they were among the main ideological currents of Czech society in the period 1848-1900.

It should also be noted that the introductory pages of the text are conceived more broadly, i.e. from the perspective of cultural studies. I have seen many times that knowledge of the development of both traditions as a prerequisite for understanding the context cannot be automatically assumed in the musicological environment. Most of the text is, of course, filled with musical historiography divided into following the development of the traditions separately, but also into compositions intertwining the two traditions.

\section{Searching for Common and Different Elements}

As indicated in the introduction, each of the two traditions in question entered the 19th century from a different position. The basic difference can be expressed simply: the Saint Wenceslas tradition had existed in an uninterrupted form since the 10th century. It was an integral part of church life, Duke Saint Wenceslas was perceived as the country's patron saint by both the Czech and German-speaking population, his legacy was part of the state representation, ${ }^{2}$ and the main symbol of the tradition- the old Czech spiritual song Svatý Václave [Saint Wenceslas] - was perceived as one of the cornerstones of Czech history and culture, as an unquestionable authentic monument known beyond the Czech borders. ${ }^{3}$

The Hus-Hussite tradition survived in an altered form of Utraquism until the outbreak of the Thirty Years'War. During the Counter-Reformation, it was systematically suppressed, and society could not become acquainted with it until the 19th century. This also applies to the original musical culture of Hussitism, symbolised by the chorale Ktožjsú boži bojoonici [Ye Who Are Warriors of God].

It is interesting that although both chorales are spiritual songs, they were perceived differently in the 19th century: the Hussite chorale mainly as a political element, the Saint Wenceslas chorale (in addition to its role in church life)

2 Frederick V of the Palatinate (1596-1632), a Calvinist, King of Bohemia at the turn of 1619 and 1620. It was only during his short reign that the monarch deviated from the "Czech heaven", i.e. patron saints.

3 Viktor Velek, “Die St. Wenzelsche Musiktradition von ihrem Anfang bis 1848” (PhD dissertation, Universität Wien, 2008).

Viktor Velek, "Musikalische Wenzelstradition (bis 1848) im Kontext der böhmischen historischen Traditionen" (PhD dissertation, Masarykova univerzita, 2010). 
as a social song nostalgically referring to the country's history, provincial patriotism and Czech statehood without division into Czech and German branches. It is also interesting to look at the environment into which both chorales were gradually shifted by historical events: the Saint Wenceslas chorale moved from the hymnal category of "songs about saints" to the "historical songs" section of many social songbooks which also contained the aforementioned Hussite chorale. However, the Hussite chorale often appeared in the form of romanticising harmonisations for male (and later also mixed) choirs after 1860. It played the role of a fighting manifesto (e.g., in the Prussian-Austrian war conflict, at people's camps, in parliamentary elections and at events against Czech Germans); on the contrary, the Saint Wenceslas chorale was primarily an intimate plea for supernatural protection, an expression of sentiment and nostalgia, belief in the supernatural intervention, a symbol of a peaceful or compromise solution. Here, intellectual perception clashed with the world of fantasy, emotion and spirituality.

In both chorales, society looked for the author (sometimes uncritically at any cost), arguing over the suitability of using this or that source with the notation of the melody supplemented by the lyrics or just the lyrics. The lists of compositions of both traditions clearly show that a group of composers formed who had no trouble creating compositions using one of the chorales, or even both. ${ }^{4}$ The chorales played an important role in maintaining the identity of Czech compatriots: the Saint Wenceslas chorale especially in churches and at Saint Wenceslas feasts, the Hussite chorale at concerts of compatriot societies. The patriotic element of the two chorales allowed their social coexistence and had the power to temporarily overshadow political adherence and contradictions in general. Over time, Duke Saint Wenceslas, as well as Master Jan Hus and Jan Žižka, became a means of expressing irony, satire and humour for society. ${ }^{5}$ As this trend also influenced music, Jan Hus very soon received a certain "relief" in the form of biographical "songs about saints". ${ }^{6}$ Both traditions were linked to memorial places, which is well documented by musical works: in addition to the places of Hussite battles, they include Hus's native Husinec or the place where he

4 From many composers, for example, Antonín Dvořák, Josef Cyril Sychra,Vítězslav Novák, Otakar Jeremiáš and Pavel Haas.

5 V.Poláček's Déti slavných husitů [Children of Famous Hussites], approx. 1900; Karel Hašler's Svatý Václav žádá pražský magistrát [Saint Wenceslas Asking Prague City Hall], approx. 1921.

6 Píseň historická o Janu Husovi [A Historical Song about Jan Hus], incipit: "V naší české zemi stojí Husinec" [Husinec stands in our Czech land], approx. 1860.

Chvalozpèv na památku velmužú českých $M$. Jana Husi a reka Žižky [A Hymn in Memory of the Great Men of Bohemia Master Jan Hus and Hero Žižka], incipit: "Vzdávejme, bratři, skvostnou slávu velmistru, Janu Husovi..." [Let us give, brethren, magnificent glory to the great master Jan Hus ...], approx. 1868. 
died, Constance; in the Saint Wenceslas tradition it is especially Stará Boleslav, Budeč, Mariazell and St Vitus Cathedral. ${ }^{7}$

\section{0: The Return of the Chalice to 19th Century Society}

The possibility to study Master Jan Hus and Hussitism critically, objectively, in a modern way and without restrictions on the part of the Church brought with it several facts. One of them was undoubtedly Joseph II's Patent of Toleration (1781). From the point of view of the application of Enlightenment ideas, it can be understood as the rehabilitation of the remnants of the lingering evangelical underground movement. The second significant change was brought about by the Napoleonic Wars. They forced the Austrian government to look for an instrument to strengthen the Czechs' motivation in the planned fight against Napoleon and for recruitment into the newly established militia divisions and student legions. The result was unsure, and allowing the glorification of mediaeval Hussite warfare soon led to a certainly unwanted side effect: Czech nationalism against local Germans and Germans in general awoke in the Czech population. Furthermore, the ideas of resistance against the monarch (or the expression of resistance against the position of the Czech lands within the Habsburg monarchy), as well as of democratisation, solving social problems, etc. were revived. Much suggests that the Napoleonic Wars were a greater milestone for the development of Czech society than is generally believed. The renaissance of the image of Hussitism is a good example of this. It was already the second life of the Hussite tradition in the period between the Congress of Vienna (1815) and the revolutionary year of 1848 that clearly indicated a number of trends that fully developed in the second half of the 19th century.

The imaginary line behind the development until the middle of the 19th century and, simultaneously, the beginning of the reception in the second half is formed by the revolutionary year of 1848 . The answer to the question of whether it was more of Saint Wenceslas or Hussite nature is clear in the light of research: it was more Hussite, with partial coexistence of both traditions representing a very interesting and as yet unexplored research field. The change in the paradigm, which consisted in the intensification of interest in Jan Hus and Hussitism, was well described by František Michálek Bartoš: "Nevertheless, the year 1848 [...] showed much coldness to the Duke [Saint Wenceslas]. Palackýs party honoured the saint by proposing the name Wenceslas Square through Havličcek. The people replaced the lines 'banish all evil, comfort the sad' with 'banish the

7 Viktor Velek, “Dějiště husitských bitev v české hudbě 19. a 20. století," Urbánní studie 14, planned to be published in 2021. 
Germans, the strangers' in the historical song. However, the young generation has ideals other than Wenceslas and Táborites."

During the revolutionary events of 1848 , the Saint Wenceslas tradition had a more fraternal character, while Hussitism coincided with radical forces. Duke Saint Wenceslas tended to become a symbol of those who chose a cautious path, compromises, concessions and solutions through diplomacy, while the Hussite idea attracted currents favouring nationalism and radical steps. The subject of Master Jan Hus and Hussitism became a new bearer of national significance (Karel Havlíček Borovský), social dimension (Emanuel Arnold) and liberal approach (Jan Neruda). It also began to be understood as liberation from "mental serfdom” (Karel Sladkovský). František Palackýs synthesising view was also of great importance: Slavic reciprocity and Czech-German problems, portrayals of a genius military leader (Jan Žižka) and a fearless preacher (Master Jan Hus), national and democratic tendencies-these imaginary stones became another interpretive layer of the Hus-Hussite cult or tradition, turning into "[...] tones meeting the general mood: it must have been beneficial for the Žižka cult if, after the renewal of constitutional orders during new, fierce political struggles, the new Czech generation, relying on Palackýs great authority, saw that its pains had for the most part been Žižka's pains: Žižka's name was then not only a great claim to historical glory, but also became the motto in new struggles for a better Czech future". ${ }^{9}$

Naturally, the exception proves the rule. Alois Hnilička (1826-1909) was among the first to practise quoting the Hussite chorale (see his overture Táborita [The Táborite], approx. 1860), obviously experiencing the time of its origin, i.e. the democratisation process after Bach's fall, in a progressive spirit. About four decades later, he responded to the abolition of Badeni's language regulations in October 1899 differently from a musical point of view: "The essence of the idea is the depiction of disappointment, pain, defiance and plea to St Wenceslas for his help in the struggle of the Czech nation. In Chrudim on 15 March 1900." ${ }^{10}$ These words belong to the symphonic poem Finále. It is intended for a large orchestra and was first performed on December 15, 1900. The polyphonically used quotation of the Saint Wenceslas chorale serves twice as a certain epilogue: on the one hand, it appears to be an eternal memento of Czech history; on the other hand, it plays a role in connection with the title The Finale. The composer himself stated: "I think that the suggested title of the composition makes it easier to understand. With this song, I wanted to end my attempts at a musical

8 František Michálek Bartoš, Kniže Václav Svatý v dějinách a v legendě (Praha: Čin, 1929), 55.

9 Rudolf Urbánek, Žižka v památkách a úcté lidu českého (Brno: Filosofická fakulta, 1924), 125.

${ }^{10}$ Tomáš Židek, Český skladatel Alois Hnilička (1826-1909) a hudební život v jeho době (Chrudim: Město Chrudim, 2009). 
song, hence the title The Finale."11 Hnilička's work aptly documents the type of composer who was able to use the quotations from both chorales to respond to social events.

It is therefore evident that in the second half of the 19th century, the Hus-Hussite and Saint Wenceslas traditions were increasingly viewed in a non-religious way. And it should be critically added that in the case of the former also in a quite idealised way. Jan Žižka was an advocate of Czech freedom and nationality for Czech late romantics, while Master Jan Hus was a preacher of mental freedom.

\section{Development after 1848}

As the following quote suggests, the defeat of the democratic forces in 1848 brought another wave of censorship against the positive presentation of the significance of Master Jan Hus and Hussitism: "The time of the police and gendarmerie turned three faces to them [the Czechs]: absolutist, German and Catholic, and all three frowned at Hussitism. The views of Hus and Žižka became the subject of investigation by the courts martial." ${ }^{12}$ After the failure of the joint advancement of various currents in Czech politics and in the atmosphere of the emerging Czech-German conflict society, certain opinion groups were formed on the Czech scene: democratic-liberal, radical-national and moderate, uniting the Catholic Church, the Czech historical nobility and the conservative political scene. The moderate camp, together with government circles, was opposed to Palackýs concept of Hussitism, offering its own concepts, such as those created by Baron Helfert and Konstantin Höfler. ${ }^{13}$ Austro-Catholicism, strengthened by the conclusion of a concordat between Vienna and the Holy See (1855), became opposition to the national movement based on the Hussite tradition, which involved the return of the rhetoric of the Baroque Counter-Reformation interpretation (Master Jan Hus was called "a martyr of lies and disobedience").

However, the "genie let out of the bottle" during the Napoleonic Wars and reincarnated in 1848 made itself known again after the easing of conditions in the 1860s (October Diploma, 1860). Censors no longer had a chance to curb it and could only slow it down, but the status of forbidden fruit essentially led to further expansion of the cult. Hus's struggle for a fair and equal dialogue and

11 Ibid.

12 Arnošt Vilém Kraus, Husitství v literatuře, zejména nèmecké. Část III. Husitství v literatuře devatenáctého století (Praha: Česká akademie věd a umění, 1924), 190.

${ }^{13}$ Josef Alexander von Helfert, Hus und Hieronymus. Studie (Prag: J. G. Calve'schen Buchhandlung, 1853).

Konstantin Höfler, Geschichtschreiber der busitischen Berwegung in Böhmen 1, 2, 3 (Wien: Kaiserl. königl. Hof - und Staatsdruckerei, 1856-1866). 
public hearing (or, more precisely, his decisive stance against the establishment) coincided with the needs of Czech society in the second half of the 19th century. Anyone who dared to portray the Hussites as robbers and murderers was labelled an ally of the Germans, a renegade and a national traitor. The patriotically oriented part of the clergy somehow balanced on the edge: it partially admitted the positive contribution of some aspects of Hussitism (for example, the use of Czech), but stopped where the boundary of a sharp conflict with the ecclesiastical doctrine began. Dilemmas of this nature were dealt with, for example, by František Matouš Klácel and Antonín Jaroslav Puchmajer.

The fall of Minister Alexander Bach after the defeats of the Austrian army in Italy (1859) created, among other things, the conditions for the restoration of constitutionality. That was followed by a gradual renewal of the attributes of Czech patriotism, but the question is whether and how quickly Hussitism automatically became the main component of the newly defined patriotism. Apparently, it was a slower process, more precisely a certain maturation, which began to displace a number of elements well known from the musical environment, such as Slavic reciprocity - that began to be perceived as an unfulfilled unrealistic ideal, its exaggerated manifestation turned into criticism of "Hey-Slavism", ${ }^{14}$ and conflicts among the Slavs indicated the political unreality of their union.

Another element, which gradually became secondary, should also be mentioned-what strongly resonated in the first half of the 19th century was more and more considered to be pathos, especially in Czech social song: the phenomenon of mythical old famous Czechs. After 1848, it became an increasingly problematic concept, very vague in terms of temporal specification and therefore without specific content and largely imposed by censorship. It is censorship that must be taken into account where a musical equivalent of famous manuscript forgeries is suspected. This applies to the Husitska [A Hussite Song] with the incipit "Těšme se blahou nadějí” [Let Us Rejoice in Blissful Hope] by JosefTheodor Krov (1797-1859). It could only be approved by censors in a text-neutral version. Krov quite possibly included verbal and musical quotations of the Saint Wenceslas chorale in the song to obtain the censor's approval. That cannot be said with certainty: what is justified is either a historical forgery or musical humour, or an escape from censorship.

In the second half of the 19th century, despite censorship, the Saint Wenceslas tradition in the national movement was massively overshadowed by the Hussite tradition, which was perceived as closer to the contemporary ideals of

${ }^{14}$ The term denotes pathetic and demonstrative efforts to present Slavic reciprocity, whose musical symbol in the form of the Pan-Slavic anthem Hej Slovane!! [Hey, Slavs!] gave the name to the phenomenon. 
free thought and national self-confidence. However, despite the dominance of the Hussite spirit, after 1848 there were many individuals who tried to return to Duke Wenceslas his universal symbolism (acceptable to all). These included artists, because the Saint Wenceslas theme, devoid of the ecclesiastical context, was an enticing subject of the romantic spirit of the time. However, artists entered "turbulent waters": the level of anti-clericalism and radicalisation of a part of the Czech political spectrum increased, and the anti-Saint-Wenceslas trend was part of what was known as ideological Protestantism, from which a new Czech collective identity grew. This identity was opposed to everything German and everything Catholic. On the contrary, the Catholic Church and Old Czech political circles manifested their adherence to traditional values (including Duke Saint Wenceslas), ${ }^{15}$ and this conservatism logically provoked a number of attacks on the interpretation of the meaning of the country's patron saint, as well as "defences". ${ }^{16}$ The following development was well summed up by František Pokorny: "The failure of the struggle for the Czech state caused a decrease in reverence for Saint Wenceslas in our country, while the cult of Hussitism grew, because it was a symbol of light, strength and struggle." ${ }^{17}$ It can be supplemented with the following text by František Michálek Bartoš:

The last quarter-century before the war did not change this situation at all. In the young movements, the Wenceslas cult dies silently, giving way to the growing cult of Hus; it lives on in the conservative movements and parties which replaced the Old Czechs, but not without the support of the clergy elements of these parties. Both currents are not facing each other, but going side by side, as can be seen in the history of the monuments of Prague, Myslbek's on Wenceslas Square [monument to Saint Wenceslas], Šaloun's on the Old Town Square [monument to Jan Hus]..$^{18}$

15 The National Party (Old Czech National Party) still understood the homeland as the "Land of the Crown of Saint Wenceslas". What can be seen here is the Hungarian Saint Stephen model, but also the tradition from the time of Charles IV. This is clearly evidenced by the following quotation from the article "Uctívání sv. Václava v Čechách a sv. Štěpána v Uhrách” (J. Linhart, Čech 31, 280 (11 October 1906): 1, 2: "The Czech people see and feel well the obvious difference in the celebration of Saint Wenceslas in the Czech lands and Saint Stephen in Hungary. There, the entire representation of Hungary stands in the first row at the Saint Stephen's Monument on Saint Stephen's Day: the Palatine, the ministers, the nobility, the clergy, the city council, the army, students, societies, etc. In the Czech lands, only common people celebrate Saint Wenceslas's Day.”

${ }_{16}$ These attacks naturally provoked reactions in the form of "defences"- the best-known of them, very valuable with regard to the musical context, was written by Josef Kalousek: Obrana knižete Václava Svatébo proti smyšlenkám a křivým úsudküm o jeho povaze (Praha: Theodor Mourek 1872).

${ }^{17}$ František Pokorný, "K tradici svatováclavské," in Jan Hus, kniže Václav, eds. František Pokorný, František Žilka and Vojta Beneš (Praha: Svaz národního osvobození, 1929), 21.

18 Bartoš, Kniže Václav Svatý, 58. 
It should also be mentioned that the Catholic-conservative current itself sought its own approach to the presentation of the cult of Duke Saint Wenceslas. This is evidenced, for example, by the transfer of Bendl's "non-heroic, poetic, pious, naive" Baroque sculpture (1678) "from the centre to the periphery", i.e. from Wenceslas Square to Vyšehrad (1879), and by the need to create a new sculpture, in harmony with the spirit of the end of the 19th century. Ideas about the shape of the sculpture (or sculptural group) developed for several decades. A fierce struggle was waged in society over which personalities of Czech history would complement the country's main patron saint. Not allowing the synthesis of the traditions, the conservative circles celebrated victory: the selection represents the country's patron saints of the older Czech Middle Ages (Saint Wenceslas, Saint Procopius, Saint Adalbert and Saint Agnes). Can the fact that the Jubilee Provincial Exhibition (1891) and the Czech-Slavic Ethnographic Exhibition (1895) were opened with the Saint Wenceslas chorale be understood in the same way? Not entirely, because the Saint Wenceslas chorale was appropriate there as a symbol of the country's unity and antiquity. The church-religious department did not have a dominant position at the Ethnographic Exhibition, with the Catholic and Evangelical sections located in different buildings. The Saint Wenceslas and Hus-Hussite musical monuments were offered not only by these two sections, but also by the music department, managed by Hanuš Trneček. The beginning of the exhibition was dedicated, for example, to the oldest notations of the melodies of the songs Hospodine, pomiluj ny! [Lord, Have Mercy on Us], Saint Wenceslas and Ye Who Are Warriors of God, which can be understood as a form of synthesis or party-independent approach.

\section{Transition from the Abstract to the Concrete}

In the first half of the 19th century, the subject was mainly of interest to scientists, students and artists. However, the Hussite spirit of the revolutionary year of 1848 had no chance of being firmly anchored, and the "Moravian Hussitism" growing in the Pre-March period from F. M. Klácel's poems had a completely limited character and reach. This also applies to his young admirers from among the ranks of composers who composed various pieces of music based on his Hussite texts. ${ }^{19}$ Mass interest in Hussitism did not start until the 1860s. It emerged especially in

${ }^{19}$ Josef Ondřej Novotný: Šestý červenec 1415 [The Sixth of July 1415] (1841).

Ludvík Dietrich z Dietrichů: Navráceníposlů z Kostnice do Praby/Jan Hus / Šestý červenec [Messengers Returning from Constance to Prague / Jan Hus / The Sixth of July] (1843)

Hynek Vojáček-Vsacký: Hlas z Blanika [A Voice from Blaník] (1845).

František Bedřich Kott: Hlas z Blaníka [A Voice from Blaník] (approx. 1845). 
Bohemia, where the Hussite tradition was rooted in common people, drawing strength from the original places of memory.

There is also a change in composers' approach. For the first half of the 19th century, the phrase "abstract Hussitism" can be used. They knew as little about Hussitism as others, as historical science had only started working on the subject. The abstractness (expressed, for example, by the name of Gutmannsthal's composition Žižkưv sen [Žižka’s Dream]) was associated with an entertaining character (examples include the compositions Táborská polka [A Tábor Polka] and Sudomerrický kapik [A Sudoměrice Galop] by the same composer) and a certain cheap sensationalism: although the title of Kott's opera Žižkưv dub [Žižka's Oak] evokes the ideas of a military leader, battle or loss of an eye at the Rábí castle, Hussitism is completely missing both in Klicpera's play of the same name (1823) and in Kott's opera $(1840,1841)$. This approach in the sense of unfulfilled expectations met with considerable and open criticism in the second half of the 19 th century. The time required what we might call "concrete Hussitism". The content of SSmilovskýs text Žižkưv dub [Žižka's Oak] already refers to Trocnov (Žižka's birthplace). This text was set to music by Ludevít Procházka (1869) in the form of a male chorus, which can be understood as composers' interest in the new content of the old name.

Another change, also evident in music, can be called "Hussite Blaník". The significance of this mountain for the development of the Czech national revival was addressed in detail by Vladimír Macura in Česky sen..$^{20}$ Therefore, only a brief summary will be given. It is the Blaník legend that eloquently documents the association and the struggle between the Saint Wenceslas and Hussite traditions. One of a number of interpretations of the legend sees both icons at the head of the army of the Knights of Blaník: Duke Saint Wenceslas and Jan Žižka by his side. However, their "partnership" was not limited to the interpretation of the legend, and they also "met" in real life: in addition to the aforementioned historical songs in social songbooks, the traditional Saint Wenceslas's feast falling on September 28 can be pointed out. Stallholders did not only sell pictures of the country's main patron, but on that day they also expanded their offer to include pictures of Jan Hus and Jan Žižka.

\section{The Question of Choosing the "Correct" Theme}

If the composer composed, for example, a Saint Wenceslas mass, the maximum he could achieve was a review in one of the professional music periodicals such as Dalibor or Cyril. After 1860, however, works with the theme of Master Jan Hus and Hussitism enjoyed great interest among composers and authors of lyrics.

${ }^{20}$ Vladimír Macura, Český sen (Praha: Nakladatelství Lidové noviny, 1998). 
Nevertheless, the choice of such a subject did not automatically mean a smooth acceptance. Works that went beyond content clarity (glorification) faced great risks and controversies. Here are some examples.

The first two can be described as purely "Czech": when Zdeněk Fibich launched an appeal for peace in the political disputes between the Young Czechs and the Old Czechs with the opera Blanik (performed 1881), he did not meet with complete understanding. With his overture Husitská [The Hussite Overture] (performed 1883), Antonín Dvořák caused controversy in a part of Czech society by quoting the Hussite and Saint Wenceslas chorales in one composition. I will return to both works below.

Another example has the character of the clash between the German and the Czech: the choice of Hussite material complicated the life of a composer who, from the point of view of nationality, can be considered Utraquist. Around 1866, Josef Leopold Měchura (1804-1870), František Palacký’s brother-in-law, composed his Pobřeb na Kaňku [A Funeral on Kaňk] (op. 98), based on the lyrics by the popular and sought-after Alois Vojtěch Šmilovský. Having listened to the work in a private circle in Klatovy (November 1866), his friends asked Měchura to orchestrate it, and he also reworked the composition. A public premiere was planned for 7 April 1867, but—as Šmilovský recalls:

[...] the production was cancelled for political reasons. In the spring of the following year, the landowner elections to the Imperial Council were held. Having been probably persuaded by his friends and relatives, Měchura voted with the German landowners, which caused such outrage in Klatovy that most of the choir members refused to work with him. Měchura was very annoyed, and I thought that "Kaněk" [A Funeral on Kaňk] would probably be his last Czech composition. $[\ldots]^{21}$

However, as the continuation of the memory suggests, Měchura did not "shelve" the work:

Before the Umělecká Beseda concert in March 1868 [March 22, 1868], at which both "Štědrý den" [Christmas Eve] and "Pohřeb na Kaňku" [A Funeral on Kaňk] were performed, the poet Ebert stopped Měchura in front of the Žofín Hall as they came out from the dress rehearsal, grabbing his hand violently and saying furiously:

"Do you know, you wretch, what you've composed?"

"A good composition, I hope," he replied calmly.

"You've composed an apotheosis of Hussitism," the German Ebert said.

${ }^{21}$ [Alois Vojtěch Šmilovský], A. V. Šmilovského Spisy výpravné. Úbrnné vydání. Svazek II (Praha: F. Šimáček, 1881), 163-165. 
"I've composed a good composition."

Ebert bit his lips and paused. ${ }^{22}$

Based on the quotation, Ebert cannot be characterised as an avowed opponent of everything Czech. ${ }^{23}$ On the contrary, he was a genuine supporter of "Bohemianism", as a typical territorial patriot (Lokalpatriot) he strived for peaceful coexistence between the Czechs and the Germans, and already in 1848 signed a declaration by 60 writers on the equal rights of Czech and German nationality. In addition, he knew Měchura well-he had written the libretto Der Schild for him in 1843-1844. ${ }^{24}$ What does the dispute between Měchura and Ebert actually say in general? Simply put, the fact that Palackýs concept of Hussitism (Czech, anti-German) sharply contrasted with the previous content of the French-German image of Jan Hus and Hussitism. Their clash clearly documents the change in the Czech Germans' view of the ssubject-they began to perceive Hussitism as an anti-German phenomenon, due to many smaller or larger provocations. These, however, did not only necessarily have a Hussite content, their typical example being aggression incorporated into the paraphrase of the lyrics of the Saint Wenceslas chorale-specifically, the replacement of the original "banish all evil, comfort the sad" with "banish the Germans, the strangers". There are dozens of cases where the reverence for Duke Saint Wenceslas by the Czech Germans was stronger in certain locations than that by the local Czechs. On the other hand, an anti-Czech invective was often associated with Duke Saint Wenceslas - Wenceslaus became the curse Wenzelsläuse (Wenceslas's lice) and the image of a stupid Czech bore the name Václav/Wenzel/Vašek. In general, however, most Czech Germans viewed the country's patron saint as the "father of the Germans", to whom he had entrusted great educational tasks in the Czech lands. It is as if the Czech Germans created their own characteristics of Duke Saint Wenceslas, occasionally denouncing his anti-German image created by a part of the Czech-speaking population.

As has been mentioned, in the second half of the 19th century, especially in the period after 1860, Czech composers could use a much broader range of possible themes. The Hus-Hussite subject strongly penetrated into songwriting, as well as into operas, symphonic, chamber and choral works, etc. Censors tried

${ }^{22}$ Ibid.

${ }^{23}$ Karl Egon Ebert (1801-1882), from a German family in Prague, a poet, novelist, playwright and journalist.

Měchura composed choruses based on Šmilovskýs lyrics Komár, Pták čermák a Poštovský [A Mosquito, a Redstart and a Postman] (1869), performed posthumously by the Šumavan society in Klatovy in March 1870.

${ }^{24}$ The libretto set to music by Měchura was performed for a private audience in Klatovy in 1845; in the catalogue of Měchura's works, it is op. 95. 
to suppress the singing of the Warriors of God chorale at least during events of a political nature. These were "people's camps", where the musical backdrop was mainly formed by the national (later also state) anthem Kde domov mij?? [Where Is My Home?], the Pan-Slavic anthem Hey, Slavs!, La Marseillaise, the Russian anthem, and sometimes the old Czech spiritual song Saint Wenceslas (which could be heard, for example, on September 28, 1868 at the forbidden people's camp near Třebechovice pod Orebem ${ }^{25}$ ). Obviously, a part of society perceived both chorales without any problems, and that was certainly not for the reason presented by the Bohemicist Emil Pražák at the end of the 20th century based on a comparison of texts- this will be dealt with below. ${ }^{26}$

\section{Compositions}

An outline of how the development of society influenced the form of both traditions has been presented. Now is the time to move entirely on to music and specific examples.

In the period under study, Saint Wenceslas compositions can be divided into several groups, among which the dominant one is the group with smaller works intended for liturgy or sacred music (graduals, offertoria, masses, hymns, adaptations of the Saint Wenceslas chorale and other Saint Wenceslas hymnal songs for male choir, male choruses etc.).

The Hus-Hussite compositions offer a significantly more diverse spectrum of functional use and motivation: they range from street ballads, cabaret songs, social songs to choirs, marches, fantasias, symphonic poems to stage music and operas. They clearly correspond to socio-political problems (i.e., various Hus celebrations, unveiling of monuments, demonstrations, people's camps, elections, etc.).

In terms of quantity, composers were more interested in the Hus-Hussite theme. The Saint Wenceslas theme gradually ceased to be dominant from the canonisation of John of Nepomuk (March 19, 1729) and then also due to the disappointed hopes connected with 1848. Duke Saint Wenceslas did not come to help the insurgents from Blaník, and this hope was transferred to the future to Master Jan Hus and Jan Žižka.

In the second half of the 19th century, the musical form of the traditions both existed side by side and overlapped, in a certain synthesis. I have only found two synthetic works in this period, and these are united by their authors' efforts

${ }_{25}$ Pavla Obrazová a Jan Vlk, Svatý kniže Václav. Maior gloria (Praha-Litomyšl: Paseka, 1994), 200.

${ }^{26}$ Emil Pražák, "Svatováclavská píseň v husitství," in Stati o české středověké literatuře [výbor studii z let 1968-1996], ed. Emil Pražák (Praha: Euroslavica, 1996), 164-171. Originally published in Směrováni: pobled do badatelské a literárni dílny Amedea Molnára provázený príspèvky domácích i zabraničnich historikũ a teologů: [sborník k šedesátinám Amedea Molnára], ed. Noemi Rejchrtová (Praha: Kalich, 1983), 97-103. 
to demonstrate party-independent character, peace and unity. Given their work with the Saint Wenceslas and Hussite chorales, Fibich's Blanik and Dvořák's The Hussite Overture can be considered certain models not only for works created in the "long 19th century" (i.e. until 1918). These would include two compositions from 1912: the symphonic image Staromèstsky rynk [The Old Town Square] by Ladislav Prokop ${ }^{27}$ and the organ composition Piseñ národa ceského [A Song of the Czech Nation] by Joseph Bonnet. ${ }^{28}$ The stronger incentive for the use of both chorales in one composition was the period 1938-1945. ${ }^{29}$

The following table presents certain development milestones in the form of selected important compositions of both traditions. Two "unfinished" works were also included: the unfinished opera Smrt knižete Václava [The Death of Duke Wenceslas] (1868), based on A. Wenzig's libretto, was composed by František Zdeněk Skuherský, and Antonín Dvořák's Hus oratorio was only conceived. The table only presents a selection, because the list of compositions of both traditions consists of works by many "big and little maestros" or an episodic occurrence within a whole (for example, the Saint Wenceslas element in Dvořák's oratorio Svatá Ludmila [Saint Ludmila]).

${ }^{27}$ Ladislav Prokop Procházka (1872-1955), pseudonym Ladislav Prokop, a doctor and composer.

${ }^{28}$ Joseph Bonnet (1884-1944), a French organist and composer.

${ }^{29}$ Jaroslav Doubrava: 1. symfonie „chorálni" “ 1 st “Choral” Symphony] (1938-1940).

Otakar Jeremiáš: Píseň o rodné zemi [A Song about Homeland] (1939-1941))—cantata. Josef Plavec: Ve Tvém jméné! [In Your Name!] (1945))—male choir.

Vojtěch Bořivoj Aim: Utrpením a porobou k slávè/k vitézstvi / Cantata-Dialoghi et chori [Through Suffering and Subjection to Glory/Victory / Cantata - Dialoghi et Chori] (1945)—cantata.

Iša Krejčí: Temno [Darkness] (1944, revised 1951)—opera.

Pavel Haas: Suita pro hoboj a klavir [A Suite for Oboe and Piano] (1939).

Pavel Haas: Symfonie [Symphony] (1941, unfinished).

Osvald Chlubna: Jiř́ z Poděbrad a z Kunštátu [George of Poděbrady and Kunštát] (1942)—opera. Otakar Jeremiáš: Fantasie na staročeský chorál/ na staročeské chorály / Chorálni prèedehra / Chorálni fantazie - Český chorál-1938-Tent'pán velit'se nebáti [A Fantasia Based on the Old Czech Chorale/Old Czech Chorales / Choral Overture / Choral Fantasia - Czech Choral - 1938 - The Lord Commandeth You Not to Fear] (1938)—choral fantasia for orchestra. 
Searching for a programme, searching for an identity, or the Association and the struggle...

Table 1

\begin{tabular}{|c|c|}
\hline 1840 & C. Löwe: Johann Hus [John Hus] (oratorio) \\
\hline 1848 & $\begin{array}{l}\text { V. B. Michálek: Svatováclavský pochod [The Saint Wenceslas March] (march } \\
\text { for piano) } \\
\text { B. Smetana: Píseň svobody [The Song of Liberty] (song) } \\
\text { F. Škroup: Drahomíra [Drahomíra] (opera based on German lyrics, followed } \\
\text { by Czech translation) }\end{array}$ \\
\hline 1860 & M. Mösner: A fantasia based on Czech national historical songs \\
\hline 1862 & B. Smetana: Tri jezdci [The Three Riders] (male chorus) \\
\hline 1867 & $\begin{array}{l}\text { J. L. Měchura: Pohřeb na Kaňku [A Funeral on Kaňk] (cantata with orchestra) } \\
\text { K. R. Šebor: Drahomíra [Drahomíra] (opera) }\end{array}$ \\
\hline 1868 & $\begin{array}{l}\text { K. R. Šebor: Husitská nevěsta [The Hussite Bride] (opera) } \\
\text { B. Smetana: Česká píseň [Czech Song] (cantata for mixed choir and orchestra) } \\
\text { F. Z. Skuherský: Smrt knižete Václava [The Death of Duke Wenceslas] } \\
\text { (unfinished opera) }\end{array}$ \\
\hline 1869 & $\begin{array}{l}\text { B. Smetana: Slavnostni předehra [A Ceremonial Overture] } \\
\text { K. Bendl: Umírající husita [The Dying Hussite] (dramatic scene, male chorus } \\
\text { with orchestra) } \\
\text { Č. Vinař: Husitská nevěsta (or, as the case may be, Husitská žena) [The Hussite } \\
\text { Bride / The Hussite Woman] (unfinished opera) }\end{array}$ \\
\hline 1870,1871 & $\begin{array}{l}\text { K. Bendl: Kališníci [The Calixtines] (male chorus with orchestra) } \\
\text { K. Bendl: Bratři z kalicha [The Brethren of the Chalice] (choral scene, male } \\
\text { chorus) } \\
\text { K. Bendl: Smrt Prokopa Velikého [The Death of Prokop the Great] (male } \\
\text { chorus with orchestra) }\end{array}$ \\
\hline $\begin{array}{l}1872 \\
1872(1880,1885)\end{array}$ & $\begin{array}{l}\text { E. Nápravník: Jan Hus [Jan Hus] (unfinished opera) } \\
\text { B. Smetana: Libuše [Libuše] (opera) } \\
\text { A. Dvořák: Dědicové Bílé Hory [The Heirs to the White Mountain] (without } \\
\text { the Hussite part of Hálek's text) }\end{array}$ \\
\hline approx. 1871 & $\begin{array}{l}\text { K. Bendl: Ktož jsú Boži bojovníci [Ye Who Are Warriors of God] (harmonisation } \\
\text { for male chorus) } \\
\text { K. Bendl: Svatý Václave [Saint Wenceslas] (harmonisation for male chorus) }\end{array}$ \\
\hline 1877 & A. Dvořák: Píseň Čecha [The Song of a Czech] (male chorus) \\
\hline 1878 & B. Smetana: Tajemství [The Secret] (opera) \\
\hline 1878,1879 & $\begin{array}{l}\text { B. Smetana: Tábor a Blaník [Tábor and Blaník] (symphonic poems from } \\
\text { the Má vlast [My Country] cycle) }\end{array}$ \\
\hline
\end{tabular}

30 Tyl's play Drahomíra dates from 1849. 


\begin{tabular}{|c|c|}
\hline $1881(1874-1877)$ & $\begin{array}{l}\text { Z. Fibich: Blaník [Blaník] (opera) } \\
\text { M. Lysenko: Jan Hus [Jan Hus] (cantata) }\end{array}$ \\
\hline 1883 & $\begin{array}{l}\text { A. Dvořák: Husitská [The Hussite Overture] (orchestral overture) } \\
\text { Z. Fibich: Drahomíra [Drahomíra] (stage music based on lyrics by J. Vrchlický) }\end{array}$ \\
\hline 1885 & $\begin{array}{l}\text { V. Suk: Jan Hus [Jan Hus] (symphonic poem) } \\
\text { J. Klička: Pohřeb na Kaňku [A Funeral on Kaňk] (cantata) } \\
\text { M. Leythauser: Husitská trilogie [A Hussite Trilogy] (dramatic poem with } \\
\text { music) }\end{array}$ \\
\hline approx. 1885 & A. Dvořák: Jan Hus [Jan Hus] (oratorio concept, not executed) \\
\hline $1892(1886-1888)$ & K. Bendl: Dítě Tábora [The Child of Tábor] (opera) \\
\hline 1900 & A. Hnilička: Finále [The Finale] (symphonic poem for large orchestra, op. 185) \\
\hline
\end{tabular}

Legend:

Gray background $=$ synthesis of both traditions

Black font $=$ Hus-Hussite compositions

Underlined black font $=$ Saint Wenceslas compositions or compositions with a Saint Wenceslas element

\section{Music of Separate Traditions}

\section{"A Discovered Hussite Chorale"}

In 1861, two harmonisations of the chorale Ye Who Are Warriors of God were published. Both Hynek Palla and Jan Pavel Michal Martinovský actually presented to the general public the chorale as such! ${ }^{31}$ The logical process "from monody to polyphony" somehow did not respect the course of history. Thanks to both great adaptors, the literary monument also became a musical monument. However, that was not followed by immediate and, especially, numerous application in music. So far, it cannot be unequivocally stated that these harmonisations influenced, for example, Alois Hnilička or Karel Šebor, who quoted the chorale as one of the first. The situation is also complicated by the still unprocessed compositional legacy of Josef Leopold Zvonař, the most important populariser of musical monuments of the Czech Middle Ages of his time. ${ }^{32}$ It seems that even in the specifications of the competition for the Czech national historical and comic opera (called "Harrach Prize", announced on February 10, 1861 the recommen-

${ }^{31}$ Nápèrvy pisní národních v Čechách. (Sbirka K. J. Erbena). Prüvodem fortepiana opatřil J. P. Martinovský. Svazek čtvrtý, ed. Jan Pavel Michal Martinovský (Praha: J. Hoffmann, 1862), 67.

[Hynek Palla], Píseñ Táborů. Kdož jste boží bojovníci - Píseñ válečná Taborytů (Praha: F. Śír, 1861).

${ }^{32}$ Zvonař did not include the Hussite chorale in his cycle Hudebni památky české (vúbor krásných zpèrvi českých, církevnich i světských pro smišsený $i$ mužský sbor v pưvodni skladbě $i$ v novém upravèni sprüvodem piana i bez prüvodu z rozličných zpèvnikủ staročeských, 4 volumes from 1862-1864), but the Saint Wenceslas was published there. 
dation to take into account "antique chorales" and choose "a historical story from the history of the Bohemian Crown" meant the spiritual songs Saint Wenceslas and Lord, Have Mercy on Us rather than the Hussite chorale.

The use of the Warriors of God chorale was long hindered by the popularity of J. T. Krov's pseudo-Hussite song (called A Hussite Song or referred to with the text of the incipit, i.e. "Těšme se blahou nadějî" [Let Us Rejoice in Blissful Hope]). This curiosity of Czech music can be found, for example, in the stage music by František Škroup (1801-1862) for Kolár's drama Smrt Žižkova [The Death of Žižka] (premiered on November 17, 1850). It is worth noting that in No. 10 Škroup did not use the passage from Krov's song with a quotation of the Saint Wenceslas chorale. Whether this passage did not suit the content of the play or whether Škroup already rightly doubted the historical authenticity of Krov's song cannot be ascertained. He created his own music for No. 6 (Sbor busitu [The Hussite Choir]), but that was replaced by later promoters of the play with the chorale Ye Who Are Warriors of God. This is an obvious example of an update.

\section{Bedřich Smetana-A Hussite Composer}

"It is characteristic that The Song of Liberty does not mention the second tradition of the nation-the Saint Wenceslas tradition." ${ }^{3}$ —Before discussing Smetana's choir Tři jezdci [The Three Riders], his revolutionary barricade Píseñ svobody (Válka, válka!) [The Song of Liberty (War, War!)] from 1848 should be briefly mentioned. It represents a group of about thirty songs from 1848 with a Hus-Hussite element. ${ }^{34}$ What seems interesting is the fact that the ten stanzas of Píseň svobody [The Song of Liberty] by Josef Jiří Kolár ${ }^{35}$ contain several Hussite elements, but not a single Saint Wenceslas element. ${ }^{36}$ - An accurate understanding of the introductory quotation should be facilitated by the note that in 1848 not only songs with a Hus-Hussite theme were composed, but also songs combining this and the Saint Wenceslas theme, as well as (to a lesser extent) purely

${ }_{33}$ Jaromír Metyš, "Husitské prvky v díle Bedřicha Smetany," Náboženská revue Církve československé 30, No. 4 (1959): 176.

${ }^{34}$ Viktor Velek, "1848: Music and Master Jan Hus and Hussitism," paper at the international musicological conference "Music, Arts and Politics: Revolutions and Restorations in Europe and Croatia, 1815-1860", Zagreb 16-19 October 2019. To be published.

35 Smetana had known Kolár's daughter Kateřina (1827-1859) since 1842 and married her in 1849.

${ }^{36}$ It is little known that the same text was also set to music with the title Válka [War] by Arnošt Mašek, in 1848 the choirmaster of the Academic Singing Society in Prague, a friend of the radical J. V. Frič. So far the oldest known performance of this male choir dates back to May 5, 1851 (Prague's Žofín, conducted by F. Škroup). 
Saint Wenceslas compositions. ${ }^{37}$ Smetana's song was also an inspiration in the 20th century. Josef Stanislav wrote in Hudebni rozhledy that he had studied Smetana's The Song of Liberty because of the composition of socialist "mass song". ${ }^{38}$

As a composer (and also as a person), Smetana was "untouched" by the Saint Wenceslas theme; on the contrary, he remained faithful to the Hus-Hussite tradition throughout his work. ${ }^{39} \mathrm{With}$ the selection of the subject, the male chorus The Three Riders from 1862 followed the "pre-March" compositions by young Moravian composers, namely Josef Ondřej Novotný and Ludvík Dietrich of Dietrich. ${ }^{40}$ They quickly responded to the Hus-Hussite elements in the poems of their spiritual leader, F. M. Klácel. Approximately twenty years later, however, Smetana used a similar content model by the poet Vratislav Jiljí Jahn, who had offered his lyrics Kališnici [The Calixtines] to Adolf Albert Pozděna-that was supposed to happen as early as 1859; unfortunately, no details are known about the nature of the composition and the lyrics themselves. ${ }^{41}$ The Three Riders by the Smetana-Jahn duo are a clear example of a conscious and courageous manifestation of the modern Czech political programme. The conclusion of the chorus can be understood as a threat, warning or prophecy, which came true in 1918: "Although I only have a handful of ashes, I carry the avenger's tool, a wild flame will shoot out of it to make the slaves fight."

Bedřich Smetana's male chorus entitled Česká piseñ [Czech Song] dates back to 1868. The attentive listener will notice a quotation of Husitský Oť́enás [The Lord's Prayer of the Hussites] in the 1st movement. Smetana was thus the first to introduce this important monument of the Hussite Middle Ages, at a time when society was still enthralled by Krov's ahistorical song and when the Warriors of God chorale was just gaining a firm place in society's life.

37 For example, Svatováclavský pochod [The Saint Wenceslas March] by Václav Bohumil Michálek (Swato-Wáclawský Pochod pro pianoforte. Wènowaný wlasteneckému sboru Swornosti na dỉkaz bratrwstwa od Wácl. Bohumila Michálka, člena druhé setniny Swornosti. Praha 1848, published by the composer to be sold by Jan Hofmann).

${ }^{38}$ Josef Stanislav, “Čs. skladatelé píši nové opery. K otázkám komposice husitské opery,” Hudební rozbledy 3, No. 4 (20 November 1950): 9.

${ }^{39}$ Metyš, "Husitské prvky," 173-183.

${ }^{40}$ Klácel's poem 6. červenec [6 July] (1836) was set to music by Novotný as Šestý červenec 1415 [The Sixth of July 1415] (1841) and by Dietrich as Navrácení poslü z Kostnice do Praby/Jan Hus / Šestý cervenec [Messengers Returning from Constance to Prague/ Jan Hus / The Sixth of July] (1843); a response in Prague was probably the male chorus Šestý červenec/Šestý červenec 1415 [The Sixth of July / The Sixth of July 1415], composed in 1846 by František Arnold Vogel, at that time a teacher of choral singing at the Prague Conservatoire.

${ }^{41}$ This is stated (without specifying the year) by Emanuel Antonín Meliš, Prüvodce hudebni a divadelni vydán $k$ upomince na slavnostni položeni základnỉho kamene $k$ velikému národnímu divadlu v Praze (Praha: Mikuláš \& Knapp, 1868), 57. 
George of Poděbrady is considered a "Hussite king". For the tableau vivant of "the new elected King of Bohemia greeted by Jan Rokycana in the Týn Church", Smetana composed Slavnostni predehra [A Ceremonial Overture], which was first performed on May 16, 1869 in the New Town Theatre by the Umělecká Beseda society. However, although the overture cannot be considered a "pure" Hus-Hussite work, it was already mentioned marginally in this context by Vladimír Helfert. ${ }^{42}$

Smetana apparently did not view The Lord's Prayer of the Hussites as a musical monument that should become a musical symbol for his generation and beyond. It was already in Libusse (1872) that he indicated that he would return to the Warriors of God chorale - at the end of Má vlast [My Country]. Although the drama Libussa by Franz Grillparzer (1847) ends with a depiction of mourning over the end of the mythical period, Smetana used Wenzig's libretto to manifest the glorious future growing out of Hussitism:

$[\ldots]$ where the national drama culminates in a prophecy in which it clearly stands out as the supreme image of Hussitism? Where the Hussite warriors are the true bearers of both the struggle programme and the revolutionary democratic movement? Here, it would no longer be sufficient to only quote the Hussite chorale or Škroup's song “Where Is My Home?", as Wenzig originally asked Smetana to do. On the contrary, in Libuše's prophecy, in accordance with the entire ideological intention of the ceremonial finale, Smetana uses the Hussite chorale to create a number of powerful images where the intonations of the Hussite chorale are transformed based on the content and idea of the opera's finale. Always in such a way that the Hussite music, transformed into massive images, underlines what is happening on stage. (The Hussite march, George of Poděbrady - the Hussite chorale is transformed into a war march here). Similar content changes of music can be found in Tábor and Blaník. Here, the Hussite singing, transformed once, for example, into a war march, then into a pastorale, etc., forms massive images, developed into the large area of a symphonic poem. It is then necessary to realise that these rich content transformations result directly from the entire ideological concept of Smetana's music. ${ }^{43}$

The inclusion of the preceding quotation requires some clarification. Specifically, the point is who of the Wenzig-Smetana duo actually gave Libuše a partial Hussite character:

42 Vladimír Helfert, “Boží bojovníci’ v české hudbě 19. století (k dvojímu letošnímu jubileu),” in Sbornik Žižkưv 1424-1924 k pètistému výročí jeho úmrtí, ed. Rudolf Urbánek (Praha: Vědecký ústav vojenský, 1924), 280.

43 Zdeněk Sádecký, Boj za demokratickou piseň v obrození (Praha: Orbis, 1952), 69. 
At first glance, it would seem that Smetana was brought to the act of setting the Hussite idea to music by Jos. Wenzig, the librettist of "Libuše", in which Hussitism interferes with the musical organism of the work for the first time. However, this is not the case. First, the Hussite idea does not dominate in Wenzig's libretto of "Libuše" (approx. 1866). [...] Smetana supplemented Wenzig and [...] the culmination of "Libuše" with the Hussite war chorale is, in terms of both ideology and music, entirely Smetana's work. In addition, Wenzig's other literary work shows that until 1870 the Hussite idea was unimportant to him. [...] Let it be emphasised that in the six scenes of Libuše's prophecy this image of Hussitism does not appear in Wenzig's work in any way as climactic, i.e. the Hussite idea is not dominant in his conception of the main Czech historical moments. It was only after Smetana's setting to music, and probably also as a result of his influence, that the Hussite idea penetrated deeper into Wenzig's literary work. ${ }^{44}$

Bedřich Smetana returned to the quotation of The Lord's Prayer of the Hussites once again, in the bridesmaid song in the opera The Secret (1877-1878). The highest Hus-Hussite value is represented by the finale of his cycle of symphonic poems, My Country. Smetana could use the Saint Wenceslas element in the Blanik part, but unlike Fibich, he only viewed it in the Hussite way. In the progressive part of the Czech political scene, Smetana met with great success. Much has been written about the ideological content of My Country and its Hussite nature, so further description would be redundant. ${ }^{45}$

\section{Karel Richard Šebor-A Composer of Two Separate Traditions}

"In the nineteenth century the Václav cult excited the visual arts rather more than dramatic ones, which preferred his formidable mother Drahomíra." ${ }^{46}$ - John Tyrrell's introductory quotation can be supplemented by the fact that, together with Duchess Drahomíra, Wenceslas's fratricide Boleslav (clearly a more attractive character for playwrights) also entered the scene. Duke Saint Wenceslas is included in the stories of two operas entitled Drahomira. However, it seems that over time his potential for dramatic use disappeared-in 1848, F. Škroup used the saint at least as an episodic character (German libretto by V. A. Svoboda), but in K. Šebor's opera from 1867 the audience was only offered the saint as a silent, voiceless apparition. His Drahomíra was based on the text by František Šír, a poet who had written lyrics for the celebratory cantata/chorus for the 400th anniversary of the Battle of Vítkov shortly before $1820 !{ }^{47}$ Śír's Drahomíra was adapted for the needs of the opera libretto by Jindrich Böhm. The reviewers criticised the

${ }^{44}$ Helfert, "Boží bojovníci," 275, 276.

${ }^{45}$ Metyš, "Husitské prvky,"173-183.

${ }^{46}$ John Tyrrell, Czech Opera (Cambridge: Cambridge University Press, 2005), 127.

${ }^{47}$ However, censors banned this chorus from being performed in its original Hus-Hussite form. 
excessive length of the opera, the influence of foreign composers and monotony. The Saint Wenceslas chorale is not quoted in the opera.-S Sebor presented the story of a mother/duchess who does not get rid of her pagan roots and initiates the murder of her son Wenceslas with the help of her second (younger and power-hungry) son Boleslav. There was nothing socially relevant about the subject, so the public could be surprised more by the development after the fratricide, i.e. the alienation of Drahomíra and Boleslav. He felt remorse, and Drahomíra sank into the ground, where she was consumed by flames. It might be of interest that a drama about Drahomíra was also planned by the famous Austrian playwright Franz Grillparzer - the musical "end user" was to be Ludwig van Beethoven.

With the aforementioned opera, Šebor drew a long imaginary line under the theme "Saint Wenceslas in opera". His next, third opera then introduced the Hus-Hussite subject into the operatic genre. His Husitská nevèsta [The Hussite Bride], performed for the first time on September 28, 1868 (i.e., on the feast of Duke Saint Wenceslas!), is often mentioned mainly as the work in which the chorale Ye Who Are Warriors of God was first used in the form of a musical quotation. A few years ago, Jakub Žídek found a quotation in Alois Hnilička's slightly older composition The Táborite. However, Sebor was the first quoter in Czech opera. Gone were the Italian elements and, on the contrary, the opera revealed the influences of French grand opera. Both The Hussite Bride and Drahomira have one element in common: the absence of a connection to current socio-political events. The story describes the dilemma of two lovers who discover that they are a brother and a sister. The Hussite theme is just the scene where the drama takes place. However, by choosing this period, Šebor showed a feeling for fulfilling the expectations of his peers.-For the sake of interest or completeness, it can also be added that the libretto by Eduard Herold is also entitled Husitská nevěsta (or, as the case may be, Husitská žena) [The Hussite Bride / The Hussite Woman]. In 1869, Čeněk Vinař, the choirmaster of Prague's Church of the Holy Spirit, began to set it to music, but did not complete the work. Herold was probably influenced by the fact that it was he who created the stage decorations for Šebor's The Hussite Bride.

\section{The Hussite Operas by Šebor and Bendl-Operas without a Connection between the Middle Ages and the Present}

From a chronological point of view, it is now a good opportunity to mention the year 1885, when a competition was announced for a Hussite opera: "A. Neumann, a well-known patriot, has donated 100 guldens in a 5\% paper annuity as the first contribution to the prize to be awarded to the composer and the author of the libretto of a great patriotic opera from the Hussite period whose 
protagonist must be either Žižka or Jan Hus. Mr Neumann also invites friends of Czech music to follow his example." 48

It was certainly not an impulse to write the opera Dité Tábora [The Child of Tábor], because Eliška Krásnohorská had worked on the libretto in 1876-1884, with Bedrich Smetana supposed to set it to music. Finally, the libretto, which won the new opera competition for the second opening of the National Theatre in 1884 , was set to music by Karel Bendl in 1886-1888. The opera was first performed on March 14, 1892, but was only rerun four times (it was awarded the 1st prize of the Czech Academy of Sciences and Arts). It is interesting that Krásnohorskás libretto returned onto the theatre stage the legend of how the Hussites spared the besieged town of Naumburg - this motif had been popular all over Europe especially around 1800!

Let me include a small contextual intermezzo: in 1869-1871, the Hus-Hussite subject was clearly dominated by Karel Bendl. He co-founded the famous Prague choir Hlahol (1861) and, after the resignation of Bedřich Smetana from the position of choirmaster, he led the Hlahol choir in 1865-1877. The beginning of this period is related to both the war with Prussia and the Austro-Hungarian settlement. Both events significantly affected the development of Czech society. It would be possible to add the transport of the Czech coronation jewels from Vienna to Prague, the demonstrations connected with people's camps, the first pilgrimages to Constance, the collection of the foundation stone for the $\mathrm{Na}$ tional Theatre, the first important Hus feast in Prague (1869 to commemorate the 500th anniversary of Master Jan Hus) and many other events to which the modern reception of Hussitism could be related.

Karel Bendl is one of many who transmitted the Hus-Hussite atmosphere of this period to music, most often in the form of male choruses with orchestral accompaniment. Unfortunately, nothing from the group of Umirajici busita (or, as the case may be, Husita) [The Dying Hussite / The Hussite] (1869), Kališnici [The Calixtines] (1871), perhaps identical to Bratrí z kalicha [The Brethren of the Chalice], and Smrt Prokopa Velikébo [The Death of Prokop the Great] (1871) has remained a living part of the concert repertoire. At that time, however, these were significant and influential works, the most vital being Bendl's harmonisation of the chorale Ye Who Are Warriors of God, but this will be dealt with in more detail below.

"Although the Warriors of God appeared twice in operatic work, it never happened out of ideological consistency as in Smetana's Hussite conception." ${ }^{49}$

48 “Drobné zprávy. Cena za operu z doby husitské," Dalibor 7, No. 34 (14 September 1885): 341, 355.

49 Helfert, “Boží bojovníci,” 288. 
This conclusion presented by Vladimír Helfert cannot be disagreed with, but it would be a pity not to compare Bendl's The Child of Tábor and Šebor's The Hussite Bride and attempt to find out what pushed that ideological character out of the story. The comparison is all the more surprising given that almost a quarter of a century passed between the performances of the operas!

First, let us focus on what the two operas have in common. The two most distinctive common storylines were aptly pointed out by John Tyrrell:

\section{Šebor's and Bendl's operas depict the conflict of love and duty against a wider historical canvas. In Sebor's opera, the Hussite hero [Jaroslav] loves a Catholic girl [Růženka]; in Bendl's opera, the "child of Tábor" [Hagar] attempts to find her (non-Hussite) mother in the town [Naumburg] the Taborites are besieging, and in so doing causes not only her own death but those of her Hussite betrothed and a non-Hussite suitor. Both operas are further complicated by somewhat unlikely paternity problems. Jaroslav's "Hussite bride" turns out to be his sister (incest is prevented only by their deaths on the battlefield); while the orphan Hagar discovers she is not just the "child of Tábor", but in fact also the child of the Taborite leader, Prokop, who has one of the main parts in the opera. ${ }^{50}$}

Tyrrell's perspective can be supplemented by other elements that are common to both operas:

Table 2

\begin{tabular}{|l|l|l|}
\hline & Šebor (The Hussite Bride) & Bendl (The Child of Tábor) \\
\hline betrayal & $\begin{array}{l}\text { The betrayal of Prague, allied with } \\
\text { Sigismund, leads to a threat to Tábor. } \\
\text { The betrayal of love occurs when Jaroslav } \\
\text { prefers military discipline and separates } \\
\text { from his beloved Rǔženka to leave with } \\
\text { the Hussite army. }\end{array}$ & $\begin{array}{l}\text { The betrayal is linked to the Hussite } \\
\text { Hagar: first, she helps the captured } \\
\text { German Catholic Oto escape. Then she } \\
\text { promises to capture him again, but does } \\
\text { not keep her promise. }\end{array}$ \\
\hline conversion & Rǔženka becomes a Hussite. & When dying, Oto embraces the chalice. \\
\hline $\begin{array}{l}\text { loss } \\
\text { of children }\end{array}$ & Radimský loses two children. & Prokop loses his daughter. \\
\hline love, peace & $\begin{array}{l}\text { Captivated by the beauties of nature, } \\
\text { the wounded Jaroslav longs for peace } \\
\text { and love. }\end{array}$ & Hagar: desire for peace and love. \\
\hline
\end{tabular}

There are several differences in the stories of the operas: in Bendl's opera, drama is achieved through the parts of Hagar's mothers (both her biological mother and stepmother) and Hagar's suicide at the end of the opera. Šebor's opera brings an interesting element of a miracle (the scene of a duel between the wounded

${ }^{50}$ Tyrrell, Czech Opera, 134. Bold type by the author of the study. 
Jaroslav singing the Warriors of God chorale and the nobleman Radimský interrupted by the miracle of the Virgin Mary), a gypsy prophecy of fate (the Táborites indeed lose at Lipany) and an interesting motif of the Adamites, who visit the Hussite camp and dance naked wildly.

Both operas seem to communicate the following: in the course of the story, the young people stop doubting that there is love, but the path to it is full of pain. Despite the grief over the death of their children, the fathers believe in a better future for the nation, desiring to achieve peace and unity of the nation. However, neither of the operas offered the audience something that would connect Hussitism with the present more deeply. That was achieved in a unique way in Leoš Janáček's opera Výlet pana Broučka do XV. stoleti [The Excursion of Mr Brouček to the Fifteenth Century] (1920).

The question is whether Bedrich Smetana criticised the musical or story aspects of Šebor's opera when writing the following sentences (a diary entry dated September 27, 1868): “Šebor's new opera performed: The Hussite Bride is a very shoddy work; despite its miserableness, the composer was called after every act - a bad sign of the audience's taste. ${ }^{" 1}$ The following review of one of the other performances is very clear in this respect: "We do not want to elaborate on how the composer conceived the holiest, as well as the most heroic, period of our country's history with a non-Czech, often naive spirit, nor on the foreign robe into which he squeezed the great Hussite spirit; 'The Hussite Bride' is not and never will be a Czech opera. ${ }^{52}$ This review also suggests that Šebor's musical invention was quite unoriginal, i.e. the influence of G. Verdi, R. Wagner and probably most of all G. Meyerbeer is too clear. Meyerbeer's opera Les Huguenots was copied both by the libretto (the theme of a love relationship against the backdrop of religious struggle, many characters are equivalent) and music (the quotation of the Warriors of God chorale corresponds to Meyerbeer's quotation of the Protestant chorale Ein feste Burg ist unser Gott in Les Huguenots). It is interesting how Šebor dealt with the requirement to evoke an archaic atmosphere and a national character: he chose the way of songfulness and the frequent use of unaccompanied singing and unison structure of the singing and orchestral voices.

51 Milan Pospíšil, “Karel Šebor," Harmonie 11, No. 8 (August 2003): 26. Josef Bartoš, Prozatímni divadlo a jeho opera [k 75. výroči otevřeni Prozatímního divadla] (Praha: Sbor pro zřízení druhého Národního divadla, 1938), 116.

52 “Literatura a umění - Zpěvohra," Národní listy 13, No. 261 (23 September 1873): 2. 


\section{Compositions Bringing a Synthesis of Both Traditions}

\section{Fibich's opera Blanik}

In 1874-1877, Zdeněk Fibich worked on the three-act opera Blaník, premiered in 1881. Leaving aside Krov's pseudo-Hussite song with an excerpt from the Saint Wenceslas chorale, this opera is the first work in which the chorale is quoted in its original autonomous form..$^{53}$ Nevertheless, the opera cannot be considered a purely or predominantly Saint Wenceslas work.

Although in this opera Fibich reached his peak in the depiction of the historical-romantic subject and was suitably patriotic, the work did not become a classic of Czech opera. He registered the opera in the competition for the opera intended for the opening of the National Theatre, and although he did not win, the result was an honourable mention and a recommendation for performance at the new National Theatre. However, that did not happen due to a fire in the theatre (August 12,1881), and the bandleader Adolf Čech performed the opera in November of the same year at the New Czech Theatre; it was not performed on the stage of the National Theatre until April 4,1894.

Although in Václav Kliment Klicpera's Blanik (1816) the Knights of Blaník still sang in the mountain: "Let our enemies bleed! We hold this motto sacred-we carry sharp swords for our country, and a cruel punishment for heretics!" ${ }^{54}$ the second half of the 19 th century headed towards the hussitisation of Blaník, i.e., the denial of the anti-Reformation interpretation of the anti-Hussite character of the Blaník army. Blaník had been hussitised by Klácel's poem "Hlas z Blaníka" [A Voice from Blaník] (1836), but censors immediately replaced Master Jan Hus and Jan Žižka of Trocnov with Saint Adalbert and Saint Wenceslas. ${ }^{55}$ The Blaník tradition eventually "mutated" into the image of one provincial army, jointly led by Duke Saint Wenceslas, Jan Žižka and sometimes also Master Jan Hus. In addition, the nationalisation of the Blaník theme was strengthened, although it was always a predominantly Czech-language theme.

It would be a pity not to confront Fibich's Blanik with the operas by Šebor (The Hussite Bride) and Bendl (The Child of Tábor) because, in terms of time, it was created between them. What is common is the motif of keeping faith and dividing families due to faith. Suicide or willingness to be killed has different motivations: Bendl's Hagar feels guilty about the deaths of others and about her betrayals; Fibich's Bořek throws himself against Zdeněk of Zásmuky's sword in

${ }^{3}$ Miloš Štědroň, “Svatý Václave," in Sloonik české budební kultury, ed. Petr Macek (Praha: Editio Supraphon, 1997), 888.

${ }^{54}$ František Adolf Šubert (ed.), Soubor spisủ Václava Klimenta Klicpery. Díl 2. Dramaticképráce vážné (Praha: B. Kočí, 1907), 678.

55 Set to music by Hynek Vojáček-Vsacký, František Bedřich Kott and Čestmír Vilém Gutmannsthal. 
despair over a future without his faith. However, the librettist Krásnohorská did not let Bořek die, even though, after an initial fight with $Z$ deněk, she put him in a fight for his life at the end of the opera again: he has to face his father, Catholic judge royal Jan of Dohalice (who did not know about the secret Utraquism of his son Bořek and his daughter Helena, did not want to tolerate it and decided to punish his daughter by sending her to a monastery).

In Český sen, Vladimír Macura described well how Krásnohorská handled the Blaník legend, which oscillates between the Saint Wenceslas and Hussite themes. Blanik combines reality and mysticism, so it fully reflects the time when it was created. Working with a supernatural element was not unusual: while in The Hussite Bride (libretto by Eduard Rüffer) the ring led to the discovery of the mother of Jaroslav and Rưženka, in Blaník (libretto by Eliška Krásnohorská) the ring is magical: if it is a gift of love, it leads the person who receives the ring to the holy place "which drank the blood of the martyrs", to the place offering salvation to the homeland of the divided nation. The supernatural is enhanced by the White Lady, who is the way to Blaník. And the Knights of Blaník should not be forgotten either! The question is whether it can be called the Hussite Blaník only because the ring passed from the dying Calixtine Domovít to the secret Calixtine Helena. In order to find peace, she gives it to her Catholic groom Zdeněk of Zásmuky.

Krásnohorskás Blanik is innovative in several aspects:

The protagonists gradually realise that they do not influence the course of events all by themselves. Longing for personal revenge, Bořek does not find help with the Knights of Blaník, whose mission is to help the nation in its most difficult moment. The Knights do not help Zdeněk either-their time will come in 200 years. The advice of the White Lady is for $Z$ deněk to return to the world to strengthen the nation in hope through the legend about the future help of the Blaník army. An interesting moment is self-sacrifice out of love and its supernatural appreciation: in the fight between the son Bořek and the father Jan, Helena jumps in front of her brother, and her father inadvertently runs her through with his sword. When Zdeněk puts the sword of faith in Helena's hand and places a wreath given by the White Lady by her head, a miracle happens: "Destroyed by strife, Helena comes to life in reconciliation, and everyone rejoices in trusting in the happy future of the now united homeland." ${ }^{56}$

Unlike Šebor's and Bendl's operas, Fibich's work ends happily. The same question for all three operas is whether at least the end of one of them managed to satisfy the expectations of the audience. If it did, it was only partly: these operas did

${ }_{56}$ Jaroslav Jiránek, Zdeněk Fibich (Praha: Akademie múzických umění, Hudební fakulta, 2000), 39 
not become timeless works, although from a certain point of view they met the needs of the time. In addition, compared to the others, Fibich's opera seems the least realistic, almost like a fairy tale!

The emphasis on reconciliation, with which Fibich evidently agreed, can be understood as an appeal to Czech society, divided into the Old Czechs and the Young Czechs. The former embraced values such as Duke Saint Wenceslas, the latter considered themselves the successors to the Hussites, invoking their democratic ideals and calling themselves the Hussites or the warriors of God. Blanik disappointed the Young Czechs at least in two aspects: first, the concept of reconciliation sounded too idealistic and unrealistic, and, second, Fibich chose the Saint Wenceslas chorale (see sheet music example No. 1) as a characteristic motif for the Knights of Blaník (the motif of Blaník). ${ }^{57}$ Yes, the motif of Blaník musically evokes this chorale.-The singing part with the lyrics "Our nation will never perish, it will rise from the grave, it will rise from the grave glorified" (see sheet music example No. 2) can be understood as the "anthem of the Knights of Blaník", which is in a place where the contemporary listener could expect the use of the song Ye Who Are Warriors of God. Jiři Kopecký adds the following to this opinion: "The culmination point of the opera is built on the original 7/4 meter, yet the melody is easy to remember. So, the whole theatre can sing along with Perchta and the Knights—-the same situation also occurs in the finale of Smetana's Libuše. Fibich's chorale fully replaces the Hussite song Ye Who Are Warriors of God." ${ }^{8}$

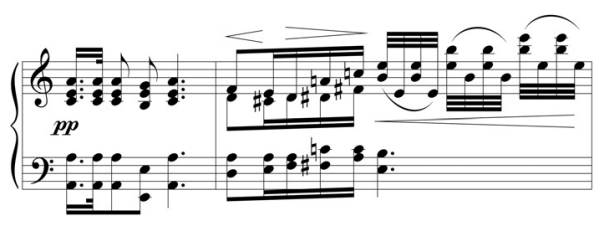

Sheet music example $1^{59}$

${ }^{57}$ Fibich showed a desire to work with musical quotations several times. For example, in the ceremonial overture Komensky [Comenius] (op. 34, 1892) he used, on the recommendation of Otakar Hostinský, the spiritual song Studně neprevéázená všech božských milostí [The Well of All Divine Graces Not Outweighed] from the Amsterdam Hymnal (1659). He performed a song from the 16th century in the opera Śáka (Proč kalino v struze stojišs [Why, Guelder Rose, Doest Thou Grow in a Gulley]), and his last opera, Pád Arkuna [The Fall of Arkona], contains the hymn Te Deum laudamus.

${ }^{58}$ Jiří Kopecký and Marta Ottlová, "Ve stínu Smetanovy Libuše: Fibichův Blaník a národní divadlo," Hudebni véda 58, No. 1 (2021): 99.

Bohumír Štědroň, "Husitské náměty v české a světové hudbě," Časopis Národního muzea, oddíl věd společenských 122, No. 1 (1953): 77.

59 The sheet music examples have been kindly provided by Jiří Kopecký. 


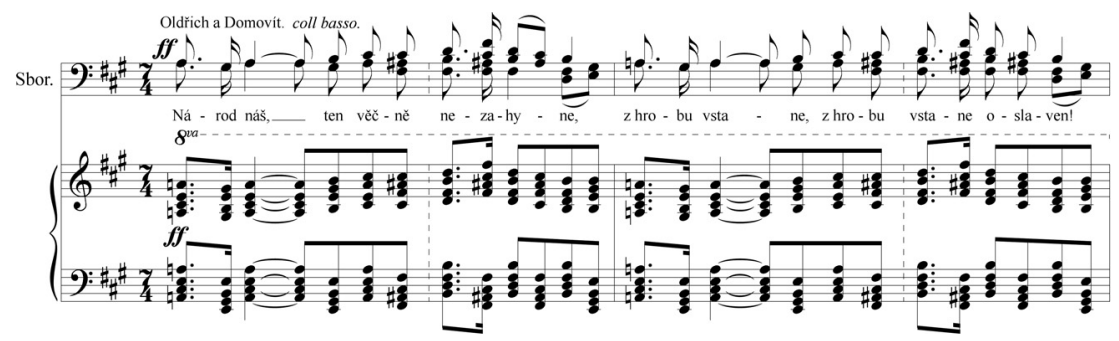

Sheet music example 2

There is no doubt that the choice of the Hussite chorale would better meet the requirements of modern national music. The libretto offered, for example, the scene of removing the chalice from the Týn Church-in connection with the mass scene of the rebellious people, this historical image has a truly magnificent effect. However, Fibich did not "make use" of the opportunity.

Jaroslav Jiránek, a leading expert on Fibich's work, offered a possible explanation for this step: "While Fibich combined his musical symbol, Blaník-completely in the spirit of folk ballads-with the quotation of the Saint Wenceslas chorale, Smetana ended this tradition, connecting Blaník, in the spirit of the progressive philosophy of Czech history, with Tábor and the Hussite chorale." ${ }^{60}$ Jiránek's conclusion opens up space for further reflection. One of the widespread theories is that Fibich did not want to imitate Smetana by quoting the Hussite chorale. One should not be confused by the mere fact that Fibich completed Blaník in 1877 and Smetana's opuses Tábor and Blaník were completed in 1878 and 1879 respectively. Fibich probably knew that Smetana had used the Hussite chorale in the opera Libuse (completed in 1872), waiting with a public performance for the completion of the National Theatre (1881). Perhaps that is why he did not choose to quote the Hussite chorale, because it would not be original.

Does it mean that Fibich's quotation of the Saint Wenceslas chorale can be considered an anachronism? This is how Bohumír Štědroň evaluated Fibich's work with quotations:

It is strange that Zdeněk Fibich (1850-1890), a great peer of Dvořák and an admirer of Smetana, did not show a clear relationship to Hussitism in his music. He was able to use a quotation of a chorale from Comenius's hymnal in the overture Comenius, he did not hesitate to present an excerpt from Smetana's Libuse in the opera Šárka, but he did not use the Hussite chorale anywhere, not even in the

${ }^{60}$ Jiránek, Zdeněk Fibich, 41. 
scene of removing the chalice from the Týn Church in Act 1 of the opera Blanik (1877). Given Fibich's progressivity, this is indeed a mystery as yet inexplicable. ${ }^{61}$

However, there are multiple hypotheses explaining Fibich's musical thinking: Fibich may not have "thought politically" and did not want to keep up with the times at all costs.

"Nevertheless, the opera cannot be considered a purely or dominantly Saint Wenceslas work." This sentence, written in the introduction to the subchapter "Fibich's opera Blanik", needs a continuation based on the previous lines: it cannot be considered a Hussite work either, although the story connected to the situation after the end of the Battle of White Mountain addresses the issue of the coexistence of Catholics and Utraquists. Nevertheless, there is room for it to be interpreted as a work synthesising the older Saint Wenceslas form and the younger Hussite form of the Blaník tradition.

\section{Bendl's Harmonisation of Old Czech Spiritual Songs}

As mentioned above, the greatest viability of all Bendl's Hussite compositions was his harmonisation of the chorale Ye Who Are Warriors of God. ${ }^{62}$ So far, I have managed to date the harmonisation only approximately-to 1871 . As with Bedrich Smetana, its basis is a younger melodic version of the chorale, the Mladá Boleslav version from $1530 .{ }^{63}$ It is worth mentioning that the harmonisation forms the content of the 44th volume of the Hlahol collection (approx. 1871), together with Bendl's harmonisation of the Saint Wenceslas chorale. ${ }^{64}$ The volume was obviously reissued later due to demand (with number 91), and both harmonisations were also included in the selective anthology of Prague's Hlahol society (1899). ${ }^{65}$ Unlike the Hussite chorale, Bendl knew the older melody of the Saint Wenceslas chorale, but did not use it: he chose the ascending melodic version, known mainly from the Saint John hymnal $(1863,1864)$.

${ }^{61}$ Bohumír Štědroň, "Husitské náměty v české a světové hudbě," Časopis Národního muzea, oddíl véd společenských 122, No. 1 (1953): 77.

${ }^{62}$ It can be assumed that this harmonisation is identical to Válečná piseñ Táborù [A War Song of the Táborites], associated with Bendl.

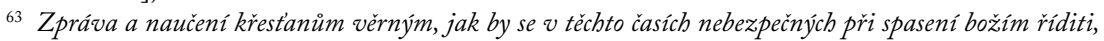
zpravovati a v ném rüsti méli, ano i prí těžkostech nynějšich, přicházejicich od násili Tureckého, jak se miti a zachovávati maji (Mladá Boleslav: bratrská tiskárna Jiříka Štyrsy, 1530), 166-168. The book contains military songs that were once sung in wars against the Turks. Published again in 1555, 1566 and twice in 1595.

${ }^{64}$ Subtitled Sbirka čtverozpèvů pro mužské hlasy [A Collection of Quartets for Male Voices].

${ }^{65}$ Sborník Pražského Hlaholu. Svazek třetí: dvacet pèt čtverozpèvư pro mužské hlasy (Praha: Em. Starý, 1899). 
This is clear evidence that Bendl saw both spiritual songs as a common historical heritage. He followed in the footsteps of his Hlahol colleague Josef Leopold Zvonař, who, however, modified both chorales separately and did not publish them in one volume. Bendl adapted the chorales for the purposes of practical choral singing without connection to the church environment, finding successors in personalities such as Josef Bohuslav Foerster, František Vránek and Jindřich Jindřich. Let us stay at a general, non-Bendl level: both chorales and other songs were then published in one of the volumes of the Vlastimil collection, specifically in 1892 to mark the 300th anniversary of the birth of J. A. Comenius. ${ }^{66}$ Another example of common "repertoire coexistence" is the inclusion of both chorales in the programme of the celebration held on June 19,1904, when Prague's Hlahol celebrated the laying of the foundation stone of the society house on a Prague waterfront. ${ }^{67}$

\section{Dvorák on the Way from Hussitism to the Synthesis with the Saint Wenceslas Tradition}

With his The Hussite Overture, Antonín Dvořák went down in history as the first composer to synthesise both spiritual traditions in music in a completely transparent way. This is especially evident when comparing this overture and Fibich's Blanik: the Saint Wenceslas subject concerns the mountain Blaník, not Duke Saint Wenceslas, and Hussitism is represented rather intuitively or, more precisely, in a form that will only be appreciated by an advanced listener. Bohumír Stědron is the author of the still valid statement that "Hussitism in Dvořák's music was not as deep and strong as in Smetana's works, but it was effective in its way, providing the Hussite idea with valuable services". ${ }^{68}$ Perhaps it can be added with regret that the subject of "Hussitism in Dvořák's music" has not yet received a well-deserved awareness, although here and there it is at least mentioned in reviews, see this example: "With his music, [Dvořák] brought fame around the world to the Hussite chorale, Czech folklore, Moravian folk poetry, as well as

${ }^{66}$ Vlastimil. Sbirka mužských čtverozpèvư svètských i kostelních ve blasech i partiture po sešitech se 6-8 sbory, ed. Roman Nejedlý (Litomyšl: R. Nejedlý, 1892). Volume No. 25 was published in 1892 to celebrate the 300th anniversary of the birth of J. A. Comenius. The subtitle "Vínek ze slovanských významných písní" [A Chaplet of Significant Slavic Songs] covers the following compositions: No. 126 Kdož jste Boži Bojovnici [Ye Who Are Warriors of God] , No. 127 Svatý Václave! [Saint Wenceslas!], No. 128 Moravo! [Moravia!], No. 129 Hospodine, pomiluj ny! [Lord, Have Mercy on Us], No. 130 S požárú dýmem [With the Smoke of Fires], No. 131 Amen rač to, Bože, dáti [Amen! May God Grant Us Our Pray'r!] (Krov's pseudo-Hussite song with the incipit “Těšme se blahou naději”" [Let Us Rejoice in Blissful Hope]), No. 132 Bývali Čechové [The Czechs Used To Be].

${ }^{67}$ The following five songs were performed: Saint Wenceslas - Lord, Have Mercy on Us - Ye Who Are Warriors of God - Where Is My Home? - Hey, Slavs!

68 Štědroň, "Husitské náměty,” 77. 
Slavic dance rhythms and Serbian, Lithuanian and Russian songs." ${ }^{\prime 9}$ Everything could have been paradigmatically different if Dvořák had started to consider the composition of the oratorio Jan Hus. ${ }^{70}$ Finally, he composed the oratorio of Svatá Ludmila [Saint Ludmila] (1886), which allowed him to use Old Slavonic heritage through a quotation of the song Lord, Have Mercy on Us!.

Before The Hussite Overture is dealt with, it is appropriate to present Dvořák's "Calixtine" compositions, which form certain initial stages in relation to it.

Disillusionment with the Austro-Hungarian settlement is evident in the works of many different artists. Among writers, Vítězslav Hálek is a typical example. In 1869 he wrote the text Dédicové Bílé Hory [The Heirs to the White Mountain], including the "Hussite Choir" with the phrase "warriors of God":

It raised the curtain for us; we are the warriors of God for the world's eternal laws!

We bled for freedom as the world extolled bondage,

our will has faded - show us the bloom of this time!

In a way, it is a pity that this part did not interest Antonín Dvořák. He chose the final celebratory hymn from Hálek's text to be set to music. The original version from 1872 (op. 30, The Heirs to the White Mountain) was performed in March 1873 by Karel Bendl and Hlahol. ${ }^{71}$

Dvořák and Hussitism: from a chronological point of view, it is necessary to mention the male chorus Piseñ Čecha [The Song of a Czech] from 1877. The Hussite element is marginal in it, and the chorus has the same significance for the Hus-Hussite tradition, because the chorus itself was probably never performed during the composer's lifetime. Dvořák set to music a part of František Jaroslav Vacek Kamenickýs text using the melody of the Hussite chorale, namely the words "here I learned to know God".

Dvořák began fully working on the quotation of the Hussite chorale in 1883, i.e. in the orchestral work The Hussite Overture (op. 67, 1883), in combination with the Saint Wenceslas chorale. ${ }^{72}$ It will be discussed below whether or not it was a good idea. The genesis of the overture is connected with František Adolf Subert (1849-1915), the first director of the National Theatre. He intended to lay repertoire stones in the form of a Hussite trilogy (the origin of the movement, battles, peace) in the foundations of the first national stage's dramaturgy,

${ }^{69}$ Hana Šlesingerová, “1991 - Rok Antonína Dvořáka,” Rudé právo 1, No. 9 (11 January 1991), 4.

70 Štědroň, "Husitské náměty," 77.

${ }^{71}$ Revised version 1880, final version 1885.

72 Zdeněk, Nejedlý, Bedřich Smetana. Praha a venkov. Díl 3 (Praha: Hudební Matice Umělecké Besedy. Sbor pro postavení pomníku Bedřichu Smetanovi v Praze, 1929), 183. Nejedlý mistakenly claims here that Dvořák quotes Krov's song in The Hussite Overture. 
acquiring Dvořák for composing the overture. The vision of the Hussite trilogy initiated by the head of the National Theatre Opera once again demonstrates how dominant this tradition was in society. The title of the overture seems to have primarily reflected Šbert's requirement. The result is not so clear-cut; due to the use of both chorales, the title The Hussite Overture is highly debatable. In this view, I build on an older observation by Vladimír Helfert:

The Hussite chorale appears here more as a quotation, while the actual motif work is related to another [Saint Wenceslas] motif. This means that the Hussite idea is not dominant here and is exposed too externally, in the concert form. [...] Even the excerpts [from the Saint Wenceslas chorale] are used in the artistic organism of the work far more than the Hussite chorale. ${ }^{73}$

Critics attempted to interpret the "meaning of the work" (whether it is a celebration of the Hussite upheaval and struggles or a celebration of the most heroic epoch in the history of the Czech nation). It would now be possible to present a number of quotations documenting how different responses were provoked by the use of both chorales in The Hussite Overture. Given the scope of the paper, only a summary is possible.

Those seeking an objective judgement interpreted Dvořák's quotation approach as a sense of sanctity and the unifying power of the Saint Wenceslas national idea. The historian Václav Novotný (1869-1932) presented an interesting view in the study "Tradice svatováclavská". ${ }^{74}$ In short, he expressed the opinion that the Saint Wenceslas tradition should not be underestimated, but it should not substitute or hinder the Hussite tradition either. This is how Novotný understood Dvořák's use of both chorales in The Hussite Ouverture - a similar parallel is the coexistence of Šaloun's Hus on the Old Town Square and Myslbek's Saint Wenceslas on Wenceslas Square.

The Nejedlýan anti-Dvořák clique characterised the overture as non-celebratory, grotesque-comic, parodying the Hussite chorale through diminution and a naive formal connection with the Saint Wenceslas chorale. It also pointed out the historical incompatibility of the two traditions, although Zdeněk Nejedlýs claim that the Hussites had never sung the Saint Wenceslas chorale was later proved to be wrong. Much evidence of the presence of the Saint Wenceslas chorale in the Hussite environment has been discovered..$^{75}$ The Bohemicist Emil

\footnotetext{
73 Helfert, “Boží bojovníci,” 289.

${ }^{74}$ Václav Novotný, "Tradice svatováclavská," in Naše národní tradice: cyklus přednášek O našich národnich tradicích, porádaný péć historického sboru ČsOL. a sdruženými korporacemi v Praze, ed. Jan Slavík and Václav Novotný (Praha: Svaz Národního Osvobození, 1928), 65, 72.

75 Velek, "Saint Wenceslaus," 190-197.
} 
Pražák even came up with the theory that the texts of both chorales contain the same content cores: the phrases "pray to God for us" and "blessed is he who shall go there" have the equivalents "pray to God for help" and "blessed is he who dies fighting for the truth" in the Hussite chorale. ${ }^{76}$

It was already Nejedly's peers that pointed out that placing the Saint Wenceslas cult against the Hus-Hussite cult (or vice versa) was in conflict with what had happened in the past. In the year of the thousandth anniversary of the martyrdom of the country's patron saint (1929), the historian Václav Novotný called for non-conflicting perceptions of both traditions, using also arguments from liturgical music:

And just as the new saints of the Hussite times do not interfere with the old one, so the old one was able to reconcile with the new ones. In the beginning, when, shortly after Hus's death (and then Jerome's death) his worship as a saint began, and when there were no worship songs that this worship required, it was natural to resort to what was at hand and to use ceremonial compositions on the feast of Hus which served during the church feasts of the martyrs, including the compositions for Saint Wenceslas's Day. Even later, this habit does not disappear completely, even though there are more and more special songs about Hus. And here again the new saint repays the old one the willingness with which he had helped him. We often read the note for the compositions explicitly for Hus's Day that they can also be sung on other similar occasions, especially, as is explicitly stated, on Saint Wenceslas's Day. ${ }^{77}$

\section{Conclusion}

It follows from the above that the second half of the 19th century was more interested in the Hus-Hussite subject than in the Saint Wenceslas material. It is as if Duke Saint Wenceslas resisted the transformation into an opera or oratorio form, although his life story contains a synthesis of the lives of both Master Jan Hus and the military leader Jan Žižka: the synthesis is formed by the death for faith and military achievements. What was decisive was obviously the fact that the Holy Duke in one person was too abstract a substance, growing mainly from a hagiographic rather than a historical basis and, moreover, in terms of the cult, strongly connected with pietas habsburgica (or pietas bohemica), the Catholic Church and conservatism, which is meaningfully demonstrated by the frequently mentioned Eliška Krásnohorská: in her preface to the libretto of Blanik, she clearly writes that she did not want to put the saint on the scene due to fear of profanation: "Myths about Blaník are of anti-Hussite, hence anti-nation nature;

${ }^{76}$ Pražák, "Svatováclavská píseň v husitství," 97-103.

77 Václav Novotný, Český kníže Václav svatý (Praha: Státní nakladatelství, 1929), 65. 
the notorious Catholic nobles, Ulrich of Rosenberg and Menhart of Hradec, are mentioned in them as the leaders of the Blaník army. In some, Saint Wenceslas is mentioned as the leader, but it would not be appropriate to put his personality on stage." ${ }^{\text {7 }}$ Apart from the above reasons, it is necessary to add the absence of a valuable Saint Wenceslas libretto.

On the contrary, the Hus-Hussite subject appeared to have a European dimension as early as around 1800 and was clearly more appealing to romantics. The story of the besieged German town of Naumburg was attractive, and the characters of Master Jan Hus and Jan Žižka were also popular. The 19th century across Europe could better identify with them, as evidenced, for example, by the Hus oratorio by the German composer Carl Löwe (approx. 1840) and the plan of the Russian composer Mily Alexeyevich Balakirev to set to music not only Master Jan Hus and Jan Žižka, but also the preacher Jerome of Prague (these considerations date back to 1869 !). The creation of the Hus opera can be considered a peak: Giovanni Huss, conceived in the Verdi-Puccini style, premiered in 1898 in Treviso (Teatro Sociale). In connection with the topic of the paper, it should be noted that the Italian composer Angelo Tessaro (1847-1899) used Krov's pseudo-Hussite song, containing an excerpt of the Saint Wenceslas chorale, in a prelude entitled "Preludio sinfonico. Canzone hussita". His intention was most likely not a conscious and ideological synthesis of both traditions, because he still considered Krov's song what it had been for Ferenc Liszt more than half a century before that - a Hussite song or a musical symbol of Hussitism. In my opinion, he had no idea, as a foreigner, of its authenticity: the symbolic value of the song was obviously primary.

It should also be noted that both the perspective of separate traditions and the perspective of synthesis could be supplemented by more and more examples. The subject is certainly not exhausted: it offers both "blanks" to be filled in by future research and the opportunity to seek a continuation in the 20th century.

Another possible chapter is the one that would introduce Czech composers who composed both Saint Wenceslas and Hus-Hussite works, or works with elements of these traditions. This would include, for example, František Gregora, Josef Cyril Sychra and Josef Bohuslav Foerster.

What may be of crucial importance for the "synthesis of traditions" is the mention in the journal Dalibor. Shortly before transcriptions of the Hussite chorale were published (1861, the aforementioned transcriptions by Palla and Martinovský), it informed its readers that the song Ye Who Are Warriors of God (including the Saint Wenceslas chorale) was incorporated by the Austrian harp

${ }^{78}$ Eliška Krásnohorská, "Blaník," in Eliška Krásnohorská. Výbor z díla I. Básně a libreta, ed. Zdeněk Pešat (Praha: SNKLHU, 1956), 575. 
virtuoso Marie Mösner (married name Gräfin von Spaur, 1838-1884) into her fantasia based on Czech national historical songs. ${ }^{79}$ Since the score material is not known, it can be hypothesised that it was the chorale Ye Who Are Warriors of God. Even if not, it does not alter the fact that the basis of the musical synthesis of the Saint Wenceslas and Hus-Hussite traditions dates back to 1860 and that it is connected with the Austrian composer!

\section{Searching for a Programme, Searching for an Identity, or the Association and the Struggle between the Saint Wenceslas and Hus-Hussite Traditions in Czech Music of the Second Half of the 19th Century}

\section{Abstract}

The text first of all gives a broader comparison of the development of two traditions that significantly influenced Czech society in the 19th century. Political, national and religious influences, together with the development of historical research, were reflected in artistic creation, including music. Both traditions were connected by many features: a place in Czech history, a religious basis, the element of Czech-German coexistence, partly also their incorporation into the interpretation of the Blaník legend, etc. The selection of compositions serves not only to understand the parallel coexistence of both traditions, but it is also beneficial in terms of finding compositions whose authors attempted to merge the two ideological currents. In addition to the compositions themselves, other valuable information on this confrontation is provided by contemporary materials (reviews, memoirs). The text reveals much about the composers' motivations, the risks of choosing the themes, the reception by audiences, opportunities for performances, competitors' opinions, etc. One of the main conclusions is the statement that Hus-Hussite compositions quantitatively predominated in the second half of the 19th century and that they were a symbol of the progressive current of Czech political representation. Compositions of a synthesising nature were united by an appeal to reconcile the confessionally, linguistically and politically divided nation, and, in this sense, they are closer to Saint Wenceslas compositions. As a whole, all compositions can then also be understood as a suitable addition to the reconstruction of the subject represented by the question "Wenceslas or Hus/Žižka".

79 “Slavná virtuoska...," Dalibor 3, No. 36 (20 December 1860): 290. 


\section{Hledání programu, hledání identity aneb Stýkání a potýkání svatováclavské a husovsko-husitské tradice v české hudbě \\ 2. poloviny v 19. století}

\section{Abstrakt}

Text přináší v úvodu širší srovnání vývoje dvou tradic, které v 19. století významně ovlivňovaly českou společnost. Vlivy politické, nacionální a náboženské se spolu s rozvojem historického bádání promítaly do umělecké tvorby, tu hudební nevyjímaje. Obě tradice spojovalo mnohé: místo v české historii, religiózní základ, prvek česko-německého soužití, zčásti i jejich začlenění do interpretace blanické legendy atd. Výběr skladeb slouží nejen k poznání paralelního soužití obou tradic, ale je prínosný i ve smyslu nalézání skladeb, jejichž autoři se pokoušeli o sloučení obou ideových proudů. Vedle skladeb samotných k této konfrontaci poskytují další cenné informace dobová vyjádření (recenze, paměti). Text prozrazuje mnohé o motivacích skladatelů, rizicích volby témat, o přijetí publikem, prríležitostech provádění, názorech konkurentů apod. Jedním z hlavních závěrů je konstatování, že husovsko-husitské skladby kvantitativně v 2. polovině 19. století převažují a že byly symbolem progresivního proudu české politické reprezentace. Skladby syntetizujícího charakteru spojoval apel na smíření konfesně, jazykově a politicky rozděleného národa, a v tomto smyslu mají blíže svatováclavským skladbám. Všechny skladby lze pak jako celek chápat i jako vhodné doplnění pro rekonstrukci tématu „Václav, nebo Hus/Žižka“.

\section{Keywords}

Identity; programme; music; national renaissance; 19th century; nationalism; Master Jan Hus; Jan Žižka; Saint Wenceslas

\section{Klíčová slova}

Identita; program; hudba; národní obrození; 19. století; nacionalismus; mistr Jan Hus; Jan Žižka; svatý Václav

The contribution was created as part of the project Staré mýty, nová fakta: české zemév centru hudebniho dèni 15. století/Old Myths, New Facts: Czech Lands in the Centre of 15th-Century Music. A joint project of the Masaryk Institute and Archives of the Czech Academy of Sciences and the Faculty of Arts of Charles University in Prague, CZECH SCIENCE FOUNDATION EXPRO 2019-2023.

Viktor Velek

Masarykův ústav a Archiv Akademie věd ČR, v. v. i. / Masaryk Institute and Archives of the Czech Academy of Sciences

vvelek@mua.cas.cz 